\title{
Outreach and performance of microfinance institutions: the importance of portfolio yield
}

\author{
Meyer, Julia
}

\begin{abstract}
In this paper, we examine the interaction between social outreach and financial return in microfinance. Running multivariate regression models and using 1,805 observations of microfinance institutions between 2004 and 2013, we find strong evidence suggesting that institutions with more social engagement - in terms of outreach to the poor - earn higher portfolio yields. We also find that measures of outreach are associated with increased operating expenses. As return figures are influenced by both costs and yield, and because both increase to a similar degree with the depth of outreach, these two effects lead to a zero sum result on return measures. This finding could explain why existing studies assessing the interaction between social outreach and different measures of financial performance in microfinance (such as return on assets/equity, operating expenses, operational self-sufficiency) have not produced consistent results.
\end{abstract}

DOI: https://doi.org/10.1080/00036846.2018.1564016

Posted at the Zurich Open Repository and Archive, University of Zurich ZORA URL: https://doi.org/10.5167/uzh-162877

Journal Article

Published Version

Originally published at:

Meyer, Julia (2019). Outreach and performance of microfinance institutions: the importance of portfolio yield. Applied Economics, 51(27):2945-2962.

DOI: https://doi.org/10.1080/00036846.2018.1564016 


\title{
Outreach and performance of microfinance institutions: the importance of portfolio yield
}

\author{
Julia Meyer
}

To cite this article: Julia Meyer (2019): Outreach and performance of microfinance institutions: the importance of portfolio yield, Applied Economics

To link to this article: https://doi.org/10.1080/00036846.2018.1564016

曲 Published online: 07 Jan 2019.

Submit your article to this journal 지

View Crossmark data $[\pi$ 


\title{
Outreach and performance of microfinance institutions: the importance of portfolio yield
}

\author{
Julia Meyer \\ Department of Banking and Finance/CSP, University of Zurich, Zurich, Switzerland
}

\begin{abstract}
In this paper, we examine the interaction between social outreach and financial return in microfinance. Running multivariate regression models and using 1,805 observations of microfinance institutions between 2004 and 2013, we find strong evidence suggesting that institutions with more social engagement - in terms of outreach to the poor - earn higher portfolio yields. We also find that measures of outreach are associated with increased operating expenses. As return figures are influenced by both costs and yield, and because both increase to a similar degree with the depth of outreach, these two effects lead to a zero sum result on return measures. This finding could explain why existing studies assessing the interaction between social outreach and different measures of financial performance in microfinance (such as return on assets/equity, operating expenses, operational self-sufficiency) have not produced consistent results.
\end{abstract}

\section{KEYWORDS}

Microfinance; financial return; outreach; operating expenses; portfolio yield

\section{JEL CLASSIFICATION} G21; L11; 016

\section{Introduction}

In recent years, microfinance institutions (MFIs) have become increasingly concerned with achieving financial sustainability. With the evolution of the financial systems or market systems approach (Ledgerwood 1999; Burjorjee and Scola 2015), and with changing guidelines for funders, more commercial investors - such as banks and specialized asset managers - have become involved in microfinance (CGAP 2007; Dieckmann 2007). As a result, financially sustainable institutions receive more attention than those that are not selfsufficient (e.g. Otero and Rhyne 1994). Even nonprofit organizations have begun to identify financial performance as one of their main goals (Quayes 2012). At the same time, microfinance investors base their investment decisions on not only financial but also social factors (Urgeghe 2010; CGAP 2012). Mainly in response to the increased commercialization of the industry and crises hitting several regions, the focus on social factors has gained importance. Furthermore, a focus on social factors is crucial to ensure the future responsibility of the microfinance sector
(Meyer and Krauss 2015). From the perspectives of both private and institutional investors, the social return of microfinance institutions - and the association between social return and financial performance - are thus increasingly of interest. Nevertheless, fund managers of commercial microfinance investment vehicles still do not strongly emphasize the inclusion of social factors in their investment decision processes. Several impediments are identified, including the belief that microfinance is social 'per se', the lack of standardization in the measurement of social performance, and lax regulation (Urgeghe 2012).

To date, it is not clear how financial and social factors interact in microfinance. One reason for this uncertainty is that the definition of social performance includes many different facets beyond the resulting impact. The diversity behind the concept of social performance in microfinance can be illustrated using the socalled social performance pathway, which differentiates five dimensions of social performance: Intent \& design, internal systems \& activities, outputs, outcomes, and impact (see the Social Performance Task Force ${ }^{1}$ ). Whereas the first two 
dimensions look at processes and strategies of the microfinance institutions, 'outputs' evaluates the type of client that is reached with the product offering. The outcome of microfinance services aims to capture the social and economic improvements of the clients. Impact analyses try to assess whether those improvements can be specifically attributed to microfinance services and therefore focus on the question if microfinance services help to reduce poverty and improve the living standards of marginalized households and communities (Morduch 1999; Khandker 2005; Islam 2009). Nevertheless, the causal association between microfinance and social impact in terms of poverty reduction, employment generation and entrepreneurship has not been proven (Armendáriz and Morduch 2010; Duvendack and Palmer-Jones 2011; Roodman 2012; Angelucci, Karlan, and Zinman 2015; Banerjee, Karlan, and Zinman 2015). ${ }^{2}$

The largest stream of research on the potential trade-offs between financial and social factors looks at the output aspect of social performance. Microfinance output is approximated using measures of outreach by evaluating the numbers and types of clients that are reached by the services. Existing studies that focus on the relation between output measures and financial performance have not produced consistent results. We hypothesize that different results are driven by conceptual questions concerning the definition of financial performance. Studies on financial performance focus on different financial return measures (e.g. return on assets, return on equity; financial and operational sustainability), on indicators of efficiency (cost indicators), or on yield measures (interest rates).

The main contribution of this paper is therefore to rearrange the logic of the interaction between social outreach and financial performance and to disentangle the components of the financial return measure. The fact that the direction of the interaction between financial performance measures is not unidimensional needs to be addressed. As at other financial institutions, the return figures of
MFIs are driven by yield (in general, positively) and operating expenses (in general, negatively). Consistent with other quantitative empirical analyses of microfinance, we use measures of depth of outreach as proxies for social return. We focus on two particular outreach measures: percentage of female clients and average loan distributed (in relation to GNI per capita). We benefit from a unique panel data set, which includes 1,805 observations on MFIs between 2004 and 2013, and we analyze the interaction between the two outreach measures and different proxies for financial return (portfolio yield, costs and return).

We develop four models to assess the relation between social outreach and four different financial performance measures and empirically test the models within our extensive data set. This approach enables us to compare findings across different financial return measures, and therefore to provide empirical evidence for our expectation that inconsistent findings on the relation between outreach and financial performance are mainly driven by conceptual differences in research designs. We complete the analysis by running tests for the different types of MFIs separately to cope with the heterogeneous MFI universe covered in the data set.

\section{Literature review}

The increasing interest in financial performance among microfinance institutions has led to the criticism that they might abandon their original mission of serving the very poor, who are excluded from standard financial services (Drake and Rhyne 2002; Copestake 2007). This criticism is based on the expectation that higher financial performance comes at the cost of lower social outreach (Armendáriz and Morduch 2010).

The discussion of the so-called 'mission drift' phenomenon in microfinance has further highlighted the importance of empirically assessing the potential trade-off between financial profit and outreach. Nevertheless, as noted above, existing research on the interaction between social outreach and financial return has not yielded consistent results. We have

\footnotetext{
${ }^{2}$ Impact studies attempt to measure the direct effects of microfinance in the markets by using different qualitative or quantitative approaches, (quasi-) experimental studies or (non-) randomized trials.
} 
identified three streams of literature focusing on different measures of financial performance in relation to social outreach. The first set of papers concentrates on return measures, such as financial or operational sustainability or return on assets. The second stream looks at cost measures; and for the third stream, concentrating on interest rates and yield measures, we only find two papers.

Quayes (2012) divides a sample of 702 MFIs into high- and low-disclosure MFIs based on their data and information disclosure levels. Looking at return measures, he finds a positive relation between financial sustainability ${ }^{3}$ and depth of outreach (using average loan balance divided by GNI per capita) for high-disclosure MFIs. Furthermore, the author confirms the result, also for high-disclosure MFIs, by calculating a logit model using financial sustainability as the dependent variable and endorsing that a lower average loan balance per borrower increases the probability of achieving financial sustainability. Quayes (2015) also finds a positive relation between the depth of outreach (average loan balance) and financial performance (return on assets and profit margins) using a two-stage least squares method. The author uses an instrumental variable in order to overcome the risk of endogeneity by including average loan balance in the regression, which might be correlated with the error term.

Cull, Demirgüç-Kunt, and Morduch (2007) do not find a significant relationship between profitability and average loan balance when using financial self-sufficiency (FSS) ${ }^{4}$ as the main measure of profitability and when using ROA and OSS for robustness checks. They find that larger loans imply lower average costs for both individualbased and solidarity-group lenders. Village banks are found to face the highest costs and subsidy levels, while individual-based lenders earn the highest profits with lower levels of outreach. Their analysis is based on data on 124 institutions in 49 developing countries.

Abdullah and Quayes (2016) look at the proportion of female clients as a measure of the depth of outreach and find that MFIs serving more female borrowers have significantly better financial performance (measured through portfolio yield, profit margin, return on assets, and operational self-sufficiency). They find evidence that this increase in financial return is linked to a decline in the portfolio at risk and therefore, better repayment performance, of female clients.

Paxton (2003) creates a poverty outreach measure that includes depth of outreach and scale. She finds that MFIs organized as banks and credit unions serve a large number of clients below the poverty level. Furthermore, she measures a zero or even negative - relationship between reliance on subsidies and depth of outreach, indicating that financially self-sufficient MFIs reach out to the largest number of poor people.

At the same time, researchers find that more socially oriented procedures incur higher costs (Conning 1999; Paxton 2003; Cull, DemirgüçKunt, and Morduch 2007; Hermes, Lensink, and Meesters 2011). Hermes, Lensink, and Meesters (2011) show evidence of a negative relationship between efficiency and depth of outreach, measured as the percentage of female borrowers and average loan balance. Their analysis is based on the interaction between efficiency and social return, using data on more than 1,300 MFIs. The authors use stochastic frontier analysis to examine whether there is a trade-off between outreach and efficiency for MFIs.

In a third approach, which looks at yield measures, Conning (1999) finds that institutions distributing smaller loans charge higher interest rates on average. The author differentiates between lowend microfinance lending organizations (MFOs), which serve clients with loans that are - on average - less than $20 \%$ of GNP per capita, and highend MFOs, with loans exceeding $85 \%$ of GNP per capita, on average. MFOs in between the two categories are defined as the broad-end group. In a sample of 72 institutions, staff expenses per average loan at low-end MFOs are reported to be more than three times higher than average. He also finds that low- and broad-end MFOs charge interest rates that are, on average, approximately twice as high as those charged by high-end MFOs. The reason for the higher interest rates is assumed

\footnotetext{
${ }^{3}$ Financial sustainability is here defined as OSS $>100 \%$ and takes the value 1 if OSS is greater than or equal to $100 \%$, and 0 otherwise.

${ }^{4}$ FSS measures the extent to which MFIs are able to cover their costs (considering adjustments) and is calculated by dividing adjusted revenue by total expenses adjusted for subsidies and inflation (Rosenberg 2009).
} 
to be the intention to cover higher costs. Finally, low- and broad-end MFOs are shown to have lower levels of leverage.

Di Bella (2011) analyses factors influencing interest rates in an empirical investigation. He shows that interest rate levels are positively influenced by the MFI's borrowing rates and inversely related to the average loan balance and the age of the MFI (Di Bella 2011).

To conclude, a number of studies provide evidence on the relationship between social outreach and financial performance. Nevertheless, the studies focus on different aspects of financial performance, and therefore, it is not possible to compare their outcomes.

This paper contributes to the existing literature in two important ways: First, we try to solve the puzzle of conflicting evidence created by existing papers. To our knowledge, it is the first paper that looks at the mechanisms of existing research projects, and discusses the aspects covered, the measures used, and the different outcomes resulting. Based on the findings, we test four empirical models and run regression analyses accounting for the four different types of financial return measures identified within the same data set. In a second step, we differentiate the results according to categories of MFIs in order to account for their heterogeneity.

\section{Materials and methods}

\section{Hypotheses}

In this section, we develop three hypotheses based on theoretical foundations in combination with empirical evidence (see Figure 1 for an overview of the hypotheses).
In line with the arguments of neoclassical economists, smaller loan sizes cause higher total costs for the institution and therefore reduce profits. While microfinance institutions are able to conduct social outreach by offering small loans and reaching out to very poor clients, they incur higher costs. The unit transaction costs of small loans to the very poor are high compared to the costs of larger loans. Furthermore, MFIs use very costly loan monitoring and control techniques as substitutes for absent standard collaterals (Conning 1999). Similarly, for female clients, costs are expected to be higher, mainly because poorer borrowers (among them more female borrowers) are often reached via group-lending techniques and served using close monitoring and control techniques, which implies lower efficiency (Hermes, Lensink, and Meesters 2011).

This hypothesis has been confirmed in a variety of empirical analyses (Conning 1999; Paxton 2003; Cull, Demirgüç-Kunt, and Morduch 2007; Hermes, Lensink, and Meesters 2011), which present evidence that social return (outreach) comes at lower efficiency:

- Hypothesis 1: Large outreach is positively associated with higher costs for the MFI.

The second hypothesis reflects the fact that microfinance interest rates are a function of expenses, such as financial expenses (e.g. cost of funds, capitalization rate), provisioning and operating expenses, being the key determinant (CGAP 2012). Financial expenses compile interest payments to investors and funders and are not expected to be directly linked to outreach to the poor, mainly because liabilities typically have longer maturities than assets (Dominicié 2012). The second

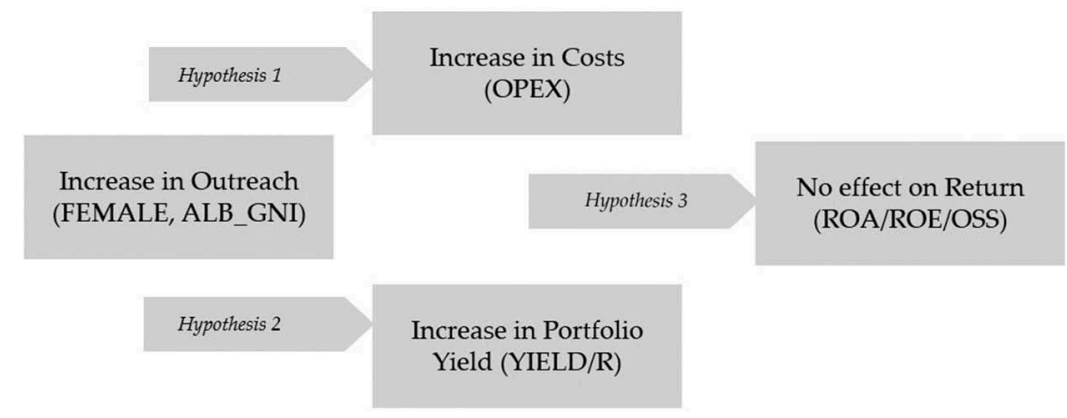

Figure 1. Overview of hypotheses. 
component, provisioning expenses, might, in turn, be related to measures of outreach, as Abdullah and Quayes (2016) find that female clients show better repayment performance and therefore, require less provisioning. This would imply that a larger share of female clients is related to lower interest rates charged. Nevertheless, the effect of female clients is twofold, as the share of female clients is also linked to higher operating expenses (see hypothesis 1), which might offset the lower provisioning effect.

Operating expenses are expected to increase with higher outreach (hypothesis 1) and as they are the major driver of interest rates charged, hypothesis 2 follows intuitively (see Figure 1):

- Hypothesis 2: Greater outreach is positively associated with higher portfolio yield for the MFI.

Empirical findings by Conning (1999) and Di Bella (2011) confirm that MFIs providing smaller average loans charge higher interest rates.

The third hypothesis follows directly from the first two and is based on the findings of Dam (2008), who states that various financial measures are diversely connected to social factors. Financial return, measured as ROA, ROE or OSS, is positively affected by portfolio yield and negatively by costs. Confirmation of hypotheses 1 and 2 would imply that outreach has a positive relation to both portfolio yield and costs, and therefore, we expect that the resulting effect on the financial return is (partially) erased (Figure 1).

The theoretical work by Stiglitz and Weiss (1981) focuses on the equilibrium of credit markets and argues that the augmentation of interest rates could squeeze low-risk clients out of the markets. Following the intuition of the agency theory, charging higher interest rates increasingly leads to issues with adverse selection and moral hazard, resulting in lower repayment rates and decreased profitability of institutions (see also Cull, Demirgüç-Kunt, and Morduch 2007). This means that in the long run, the total profitability of the institutions could suffer due to lower demand, but even more so because high-quality clients would quit borrowing.
We argue that in the short term, neither the effect of social outreach on costs, nor the effect on yield dominates, but that the two effects are of similar size. Furthermore, we do not expect a short-term effect between the higher interest rates and the quality of the loan portfolio. These arguments are supported by the fact that until now, researchers have not found a significant relationship between financial return, measured as profitability, and social outreach, measured through a variety of indicators (Cull, DemirgüçKunt, and Morduch 2007; Quayes 2012 and others).

- Hypothesis 3: Outreach is not related to the financial return of MFIs.

Nevertheless, this expected effect between the three variables of interest and the subsequent construction of hypothesis 3 entails a simplified view of the interaction between accounting figures. Cull, Demirgüç-Kunt, and Morduch (2007), for example, find that the relationship between portfolio yield and financial self-sufficiency is not linear for neither group nor individual lenders. They argue that at low levels of portfolio yield, institutions are able to increase FSS by charging higher interest rates; however, this relationship holds only up to a certain point and only for individual lenders. We expect that the relationship holds for the average MFI in our sample, as the threshold of the interest rate charged is barely exceeded, ${ }^{5}$ and most institutions in the sample act as individual lenders. To specify the results, we additionally look at the relation between outreach measures and the profit margin in the empirical analysis.

\section{Variables}

As a proxy for costs (hypothesis 1), we use operating expenses divided by assets (OPEX), as they have been found to be the most important driver of differences in total costs between institutions (Cull, Demirgüç-Kunt, and Morduch 2009). ${ }^{6}$ Operating expenses are the best indicator of the MFI's efficiency regarding lending operations (Ledgerwood 1999) and therefore an appropriate measure. To

\footnotetext{
${ }^{5}$ The average yield in our sample is at $33.9 \%$ at a nominal base and $25.4 \%$ at a real base, compared to a real gross portfolio yield of around $50 \%$, identified as a threshold in the paper by Cull, Demirgüç-Kunt, and Morduch (2007).

${ }^{6}$ In the dataset used, operating expenses and total expenses strongly correlate (coefficient of 0.92 , significant at $1 \%$ level). Therefore, the results only differ marginally if total expenses are included in the analysis instead of operating expenses.
} 
test the second hypothesis, we take gross portfolio yield on both a nominal (YIELD) and real (YIELDR) base. Portfolio yield captures average interest rates at MFI levels (González 2011).

We use the percentage of female clients and the average loan balance (gross loan portfolio divided by the number of active borrowers) of an MFI as measures of outreach. The proportion of female clients is taken as a measure of the depth of outreach because it is assumed that women are likely to be poorer, as they usually have less access to financial services (GPFI and IFC 2011). Furthermore, women have traditionally been excluded from decisions related to finance at the household level, and they often lack access to financial services (Ledgerwood 1999).

Among investors and donors, the average size of the loan is commonly used as a second proxy for an MFI's outreach to the poor (Armendáriz and Morduch 2010). Poorer clients tend to request smaller loans, and therefore, this second variable is a good proxy for outreach to the poor. However, the average loan balance is difficult to use as a standardized measure because it very much depends on the economic situation of a particular region. Therefore, we adopt an improved, standardized measure by using the average loan balance per borrower in relation to the average Gross National Income (GNI) per capita. Also, the share of female clients can be criticized for not being a perfect substitute for outreach, as, for example, there might be other reasons - beyond having a more social attitude - that could force or motivate an institution to serve more or fewer women (e.g. religious or ethical context (Urgeghe 2010)). However, data on other social performance indicators are not available for such a large set of MFIs over such a long period. Furthermore, it is the aim of this paper to solve the puzzle of existing research, and it is therefore important to use the same performance measures.

Because most MFIs are not publicly listed, accounting indicators such as return on assets (ROA), return on equity (ROE), and efficiency measures must be used as indicators for financial performance to test the third hypothesis (TchakouteTchuigoua 2010; Galema, Lensink, and Spierdijk 2011). Both ROA and ROE are widely used to measure the performance of banks and companies, as well as microfinance institutions (Ledgerwood 1999). OSS reflects the performance of institutions before subsidies. Subsidies are usually provided in the form of grants or loans at interest rates below market rates. It is likely that some institutions would not be able to maintain their performance without subsidies (Rosenberg 2009). OSS measures the degree to which operational income covers expenses. We further use profit margin, as a measure of the relation between the net operating income (YIELDOPEX) divided by operating revenue (YIELD) (CGAP/The World Bank Group 2003).

\section{Empirical model}

To estimate the model, we pool cross-sectional data on MFIs for the years 2004 to 2013, resulting in an unbalanced panel dataset. ${ }^{7}$

To test the three hypotheses developed above, we estimate the following three regression models:

Model 1:

$$
\begin{aligned}
& O P E X_{i t}=\beta_{0}+\beta_{1} F E M A L E_{i t}+\beta_{2} A L B_{-} G N I_{i t} \\
& +\beta_{3} S_{I Z E_{i t}}+\beta_{4} A G E_{i t}+\beta_{5} P A R 30_{i t} \\
& +\beta_{6} L E V E R A G E_{i t}+\beta_{7-11} L E G A L_{i} \\
& +\beta_{12-16} \text { REGION }_{i}+{ }_{17-22} \text { YEAR }_{t}+\varepsilon_{i t}
\end{aligned}
$$

Model 2:

$$
\begin{aligned}
\text { YIELD }_{i t} / \text { YIELDR }_{i t}= & \beta_{0}+\beta_{1} \text { FEMALE }_{i t} \\
& +\beta_{2} A L B_{-} G N I_{i t}+\beta_{3} \text { SIZE }_{i t} \\
& +\beta_{4} A G E_{i t}+\beta_{5} P A R 30_{i t} \\
& +\beta_{6} L E V E R A G E_{i t} \\
& +\beta_{7-11} L_{E G A L_{i}} \\
& +\beta_{12-16} \text { REGION }_{i} \\
& +\beta_{17-22} \text { YEAR }_{t}+\varepsilon_{i t}
\end{aligned}
$$

Model 3:

$$
\begin{aligned}
& R O A_{i t} / R O E_{i t} / O^{O S S} S_{i t}=\beta_{0}+\beta_{1} F E M A L E_{i t} \\
& +\beta_{2} A L B_{-} G N I_{i t}+\beta_{3} S I Z E_{i t} \\
& +\beta_{4} A G E_{i t}+\beta_{5} P A R 30_{i t} \\
& +\beta_{6} L E V E R A G E_{i t} \\
& +\beta_{7-11} L_{E G A L_{i}} \\
& +\beta_{12-16} \text { REGION } \\
& +\beta_{17-22} Y_{E A R_{t}}+\varepsilon_{i t}
\end{aligned}
$$

${ }^{7}$ Using an unbalanced dataset rather than a balanced one has the advantage of representing the market more effectively by including all MFls and preventing survivorship bias (see Baum 2006). 
The three models reflect the hypotheses developed above, whereas the relevant dependent variables used, and the predicted signs of the coefficients, differ. Outreach is measured based on two variables (female and average loan balance in relation to GNI), whereas the two expected effects are opposite, as average loan is an inverse measure of outreach.

To test our results based on the dependent variables defined above, we use an additional model specification using the profit margin as the dependent variable:

Model 4:

$$
\begin{aligned}
\text { MARGIN }_{i t}= & \beta_{0}+\beta_{1} \text { FEMALE }_{i t}+\beta_{2} \text { ALB_GNI }_{i t} \\
& +\beta_{3} \text { SIZE }_{i t}+\beta_{4} A G E_{i t}+\beta_{5} P A R 30_{i t} \\
& +\beta_{6} L \text { EVERAGE } i t+\beta_{7-11} L_{E G A L_{i}} \\
& +\beta_{12-16} \text { REGION }_{i}+\beta_{17-22} \text { YEAR }_{t}+\varepsilon_{i t}
\end{aligned}
$$

To control for other effects that might influence the relationship between social and financial return, we include several control variables. The SIZE of an institution has often been found to correlate with performance measures (Barnett and Salomon 2006; Cull, Demirgüç-Kunt, and Morduch 2007; Zacharias 2008). We include PAR30 to control for different risk structures by measuring the share of the portfolio with payments overdue by more than 30 days. ${ }^{8}$ The debt-to-equity ratio (LEVERAGE) is included as a control for different financing structures that could influence financial performance (Conning 1999; Kyereboah-Coleman 2007; Quayes 2012). To control for the structural characteristics of MFIs, we define the following fixed effects for legal status (LEGAL): BANK, COOP (credit union/ cooperative), NGO (non-governmental organization), OTHER, RURBANK (rural bank) and NBFI (non-banking financial institution). For regional fixed effects (REGION), we include dummies for Africa, Eastern Europe and Central Asia, Latin America and the Caribbean, Middle East and North Africa, South Asia, East Asia and Pacific (Cull, Demirgüç-Kunt, and Morduch 2007). ${ }^{9}$

As panel data are collected at different points in time, this analysis includes more than one observation per MFI. Consequently, the assumptions of underlying OLS-estimators may not be met, which might result in inconsistent estimators (Petersen 2009; Green 2012). One way to counter the potential for biased estimators is the use of random effects models. The random effects model is based on the assumption that the observations for one MFI tend to be related to each other over time, to a greater extent than the relations among different MFIs (Petersen 2009). Unobserved individual heterogeneity is therefore assumed to be uncorrelated with the variables that are included.

Another way to handle panel data is the use of fixed effects models. Using fixed effects is appropriate when it is expected that an effect varies over time and therefore needs to be estimated using dummy variables (measuring a group-specific constant term) (Wooldridge 2003; Green 2012). To decide which of the two models to use, we run a Hausman test (Green 2012). The null hypothesis states that the random effects model is preferred, while the alternative hypothesis favours the fixed effects model. This means that the null hypothesis does not expect the unique errors to be correlated with the regressors. In this study, we cannot reject the null hypothesis, and we decide to use the random effects model (results available in Table 1 for the variable YIELD as a dependent variable).

For the use of a random effects model, the correlation between the explanatory variables and the error term needs to be zero to ensure that the explanatory variables are exogenous. Because we cannot exclude the possibility that some unobservable effects are correlated with individual-level random effects we use an

Table 1. Hausman test: random effects versus fixed effects for YIELD.

\begin{tabular}{lcccc}
\hline & \multicolumn{4}{c}{ Coefficients } \\
\cline { 2 - 5 } VARIABLES & (b) fixed & (B) random & (b-B) Difference & S.E. \\
\hline FEMALE & .0897749 & .1044441 & -.0146692 & .013335 \\
ALB_GNI & -.0312396 & -.0334542 & .0022146 & .0026273 \\
SIZE & -.0102305 & -.0126325 & .0024019 & .0029797 \\
PAR30 & -.0296036 & -.0406403 & .0110367 & .0106251 \\
\hline
\end{tabular}

$\mathrm{b}=$ consistent under $\mathrm{Ho}$ and $\mathrm{Ha}$; obtained from xtreg

$B=$ inconsistent under $\mathrm{Ha}$, efficient under $\mathrm{Ho}$; obtained from xtreg

Test: Ho: difference in coefficients not systematic

$\operatorname{chi} 2(5)=(b-B)^{\prime}\left[\left(V_{-} \_-V_{-} B\right.\right.$ B $\left.) \wedge(-1)\right](b-B)$

$$
=5.43
$$

Prob $>$ chi $2=0.8604$

\footnotetext{
${ }^{8}$ We also analyze the write-off ratio as a control, but the results remain stable, and as the focus here is not on risk measures, only PAR30 is included in the main regression.

${ }^{9}$ The consideration of multiple dummy variables (LEGAL, REGION, and YEAR) results in different intercepts for each observation, controlling for the various fixed effects of the particular variables (Wooldridge 2003).
} 
adjusted version of the random effects model, proposed by Hausman and Taylor (1981). The use of instrumental variables within the HT model helps to overcome the potential concern of endogeneity, which is expected to prevail for the two variables of interest: FEMALE and ALB_GNI. Instrumental variables are calculated using the 'Least Square Dummy Variable' method, based on the temporal mean of the variables expected to be related to some unobservable effects. Our data hold the necessary condition to use the HT model: the number of exogenous time-varying variables is larger (or equal) than the number of endogenous time-invariant variables (Hausman and Taylor 1981).

\section{Data}

We use data on MFIs from the Microfinance Information eXchange database (MIX). ${ }^{10}$ MFIs voluntarily participate in the database. MIX does not check the reliability of each participating MFI's data, although it does perform some adjustments to make comparison easier, such as correcting for inflation, loan loss provisioning/write-offs and subsidies (MIX 2007).

Data collected by MIX are credited with being the best available representation of the top MFIs in the microfinance industry (Hartarska and Nadolnyak 2007; Krauss and Walter 2008; Di Bella 2011). Furthermore, as the data quality of the MIX database has often been criticized, MIX has implemented a rating system, using a scale of one to five, to indicate the reporting quality and completeness of the data on MFIs. In order to receive five diamonds, an MFI needs to publish audited financial statements on a yearly basis, accompanied by a rating or due diligence report. ${ }^{11}$ To ensure that the regression results are not biased by MFIs with bad reporting standards or missing information, only MFIs with five diamonds were included in the present analyses. ${ }^{12}$ The resulting data file for the purpose of the regression analysis includes 1,805 observations between 2004 and 2013, variable descriptions and descriptive statistics are presented in Tables 2 and 3.

\section{Results}

\section{Total sample}

The results for the first hypothesis are found in the HT regression using $\mathrm{OPEX}^{13}$ as the dependent variable (see column (1) of Table 5). ${ }^{14}$ The significantly positive coefficient for FEMALE and the significantly negative coefficient for ALB_GNI indicate confirmation of hypothesis 1 . Higher outreach thus comes at the cost of higher operating expenses. The results are strongly significant at the $1 \%$ level, illustrating a low probability of error. The coefficient is higher for the variable FEMALE than for ALB_GNI. Therefore, it seems to be more costly to increase outreach by targeting female clients than by reducing the average loan balances. Possible explanations for higher costs for female clients could be the increased marketing efforts required to target them or the development of groupbuilding techniques in order to meet their requirements (Hermes, Lensink, and Meesters 2011).

Evidence is also found to support the second hypothesis, which states that portfolio yield is positively correlated to outreach (see columns (2) and (3) in Table 5). The variable FEMALE shows a positive coefficient for both nominal (YIELD) and real yield (YIELDR). The coefficients for both measures are significantly different from zero at the $1 \%$ level (indicated by three stars). The more women served by an MFI, the higher the portfolio yield. The value of the coefficient (0.083) implies that institutions serving only female clients request interest rates that are, on average, 8.3 percentage points

\footnotetext{
${ }^{10}$ www.mixmarket.org.

${ }^{11}$ Four diamonds means that audited financial statements are available with lack of rating/due diligence. An institution receiving three diamonds needs to have an active profile (one diamond), some data on clients and products for the year (two diamonds) and some financial data for the year (see www. mixmarket.org/faq/diamond-rankings).

${ }^{12}$ The decision to exclude all MFIs with less than five diamonds is made because abnormal values reported by several low-diamond MFIs were discovered (for example, percentage of female customers $>100 \%$ ). Additionally, MFIs reporting negative levels of leverage (18 observations), and one observation with a leverage of over 2,000, were excluded.

${ }^{13}$ To be very consistent, we also test the hypothesis using an adjusted measure of OPEX, putting operating expenses in relation to total portfolio, rather than total assets. The reasoning behind this test is that portfolio yield is computed in relation to the portfolio, while OPEX is based on total assets. The test led to similarly significant but larger coefficients for both variables of outreach, which intuitively makes sense, as the new OPEX variable is larger due to the smaller denominator (portfolio versus total assets).

${ }^{14}$ We also present results using the random effects and the pooled OLS model, see Table 4.
} 
Table 2. Variable description.

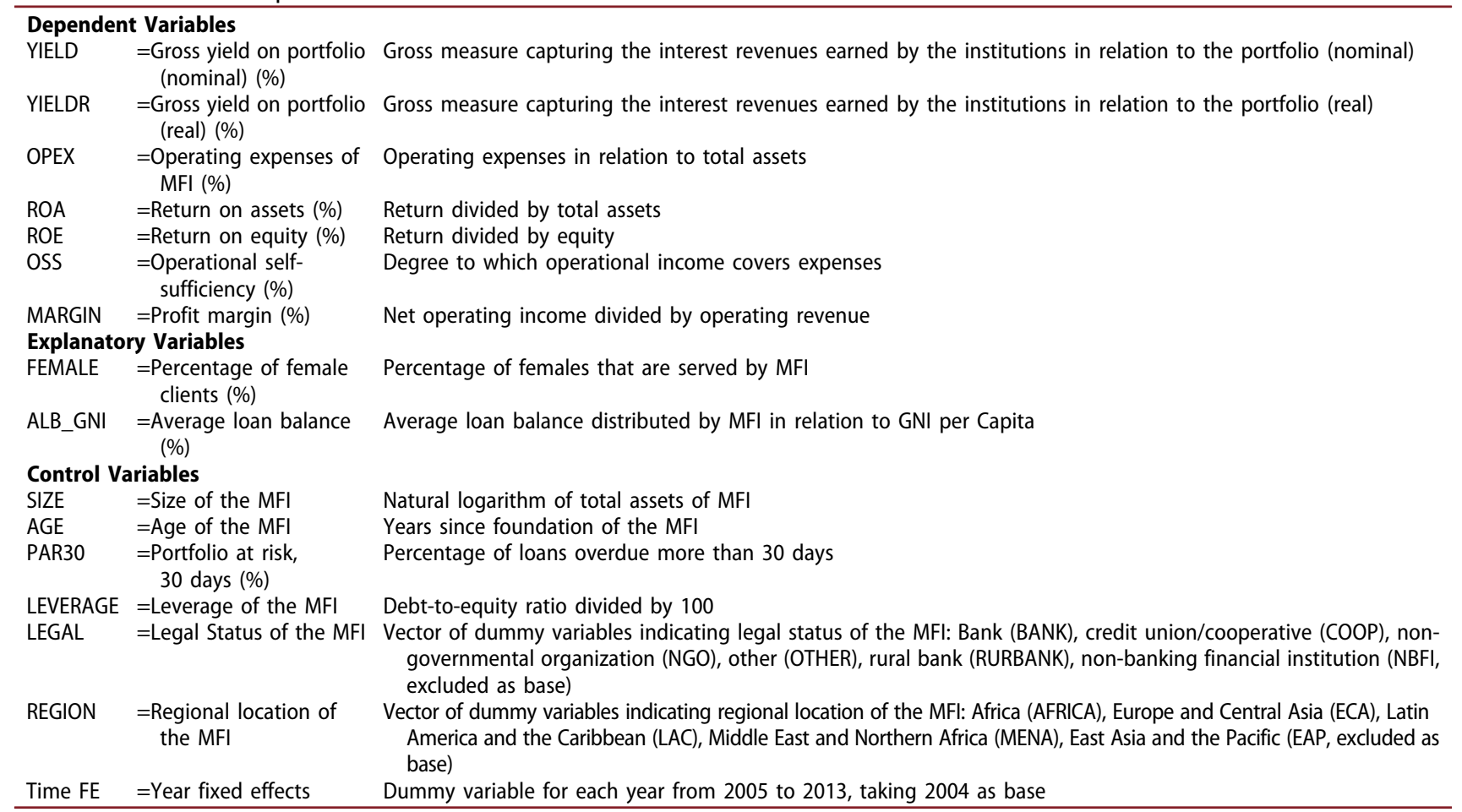

and $i=M F I, t=$ Year

Table 3. Descriptive statistics.

\begin{tabular}{lccrcc}
\hline VARIABLE & OBS. & MEAN & STD. DEV. & MIN & MAX \\
\hline YIELD & 1,805 & $33.75 \%$ & $17.23 \%$ & $4.40 \%$ & $188.36 \%$ \\
YIELDR & 1,805 & $25.16 \%$ & $17.26 \%$ & $-22.40 \%$ & $178.89 \%$ \\
OPEX & 1,805 & $17.57 \%$ & $12.04 \%$ & $1.00 \%$ & $150.15 \%$ \\
ROA & 1,805 & $2.81 \%$ & $8.23 \%$ & $-101.26 \%$ & $45.00 \%$ \\
ROE & 1,805 & $12.11 \%$ & $89.84 \%$ & $-1286.19 \%$ & $1791.28 \%$ \\
OSS & 1,805 & $121.92 \%$ & $41.26 \%$ & $13.32 \%$ & $833.88 \%$ \\
MARGIN & 1,805 & $10.49 \%$ & $35.65 \%$ & $-650.83 \%$ & $86.00 \%$ \\
FEMALE & 1,805 & $63.28 \%$ & $24.56 \%$ & $1.00 \%$ & $100.00 \%$ \\
ALB & 1,805 & 1203.08 & 1808.69 & 5.01 & $36,954.30$ \\
ALB_GNI & 1,805 & $56.68 \%$ & $74.68 \%$ & $0.28 \%$ & $773.33 \%$ \\
SIZE & 1,805 & 16.45 & 1.75 & 11.85 & 21.77 \\
PAR30 & 1,805 & $4.50 \%$ & $6.87 \%$ & $0.00 \%$ & $94.75 \%$ \\
LEVERAGE & 1,805 & 5.11 & 13.05 & 0 & 302.56 \\
\hline
\end{tabular}

higher than the rates that a hypothetical institution serving only male customers would charge. One reason for this could be that women accept higher prices for loans because they face more difficulties with regard to financial access in general.

The results are also in favour of hypothesis 2 based on the coefficient of ALB_GNI (average loan balance divided by GNI per capita) in relation to YIELD and YIELDR, which is significantly negative at the $1 \%$ level. Therefore, the lower the average loan balance divided by GNI per capita (that is, the more outreach achieved), the higher the portfolio yield for a given MFI. However, the value of the coefficient is rather small, indicating that an increase in the average loan balance in relation to GNI of 10 percentage points leads to a reduction in the yield by 0.3 percentage points. On average, higher prices are charged on smaller loans, which confirms the expectation that MFIs try to cover the higher costs incurred for smaller loans. Cross-subsidization between smaller and larger loans does, so far, not seem to occur to a significant extent.

The analysis supports the third hypothesis, based on the outreach variable ALB_GNI as we find no significant relationship between ROA, ROE and OSS and ALB_GNI (see columns (4) (5) and (6) of Table $5)$. The effect between FEMALE and the return variable ROA is similar to the effect on the yields, as the coefficient is positive and significant at the 5\% level. The outreach measure FEMALE, therefore, shows a tendency to be slightly positively correlated with financial returns, confirming previous findings on lower default rates of female clients (Abdullah and Quayes 2016). Taking profit margin (MARGIN) as a dependent variable, the relation to the two outreach variables is in line with the coefficients found for portfolio yield (column (7) of Table 5). This points to the fact that the effect between both outreach measures and YIELD slightly dominates, the one with OPEX, as the profit margin is calculated by 
Table 4. Outreach and financial performance: random effects and pooled ols using data from 2004 to 2013 (453 MFIs).

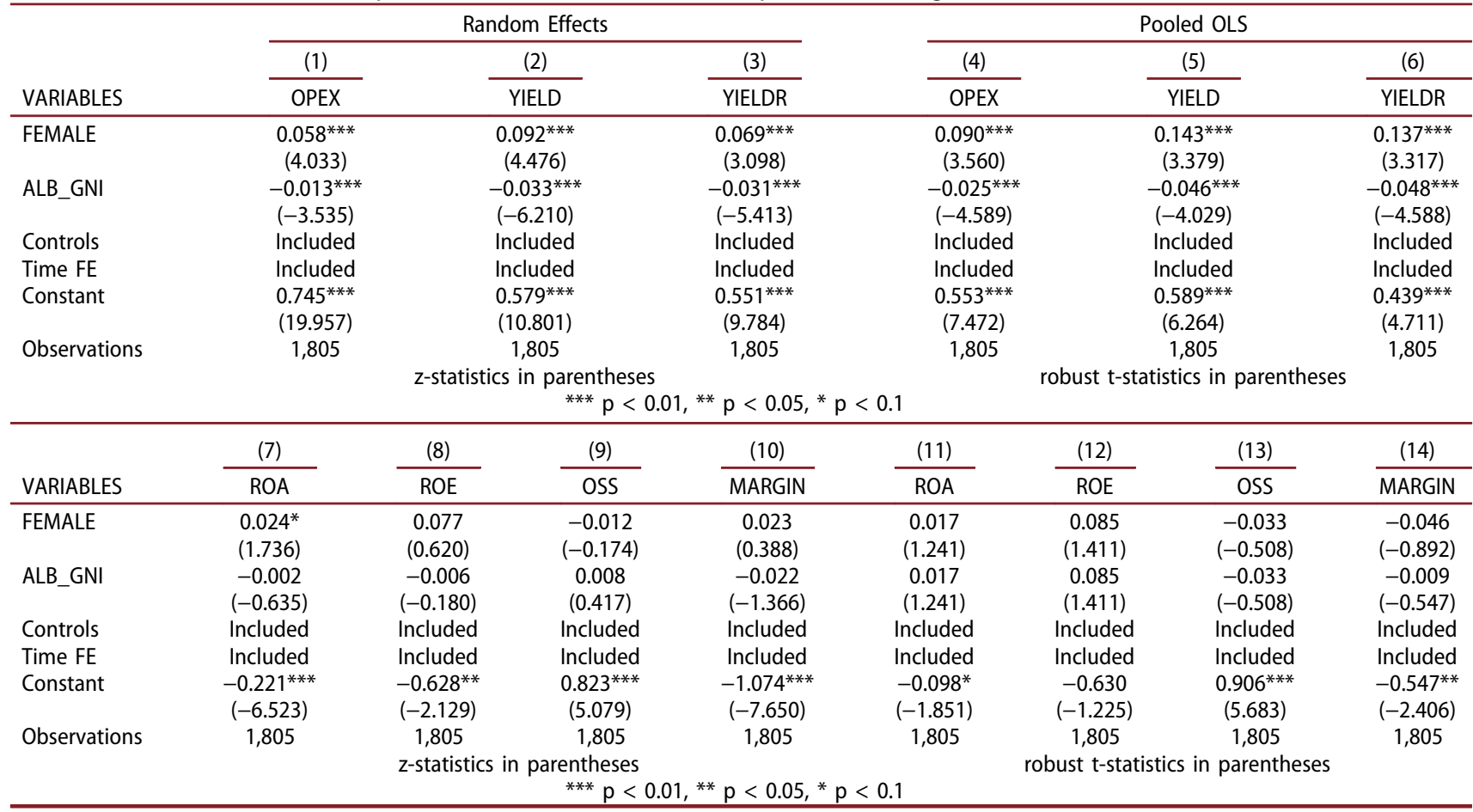

The dependent variables in this Table are the following: OPEX is operating expenses in relation to total assets; yield on portfolio nominal/real (YIELD/R) is the interest and fee income divided by the average loan portfolio; ROA and ROE are returns in relation to total assets and equity, respectively; OSS (operational self-sufficiency) is the degree to which operational income covers expenses, and MARGIN is the profit margin (net operating income divided by operating revenue). The two most important explanatory variables with respect to the Hypotheses are the percentage of female borrowers (FEMALE) and the average loan balance in relation to the GNI per capita (ALB_GNI). All explanatory variables are used as defined above.

dividing net operating income (YIELD-OPEX) by YIELD. This finding is also reflected in the positive relation between FEMALE and ROA and means that the expectation that the effects on YIELD and OPEX are of similar size needs to be scrutinized.

We, therefore, take a closer look at the data by generating a combination of the two variables FEMALE and ALB_GNI representing the level of

\begin{tabular}{cll}
\hline & \multicolumn{1}{c}{ FEMALE low } & \multicolumn{1}{c}{ FEMALE high } \\
\hline ALB_GNI & Medium Outreach & High Outreach \\
low & (FEMALE below 25. percentile; & (FEMALE above 75. percentile; \\
& ALB_GNI below 25. & ALB_GNI below 25. \\
& percentile) & percentile) \\
ALB_GNI & Low Outreach & Medium Outreach \\
high & (FEMALE below 25. percentile; & (FEMALE above 75. percentile; \\
& ALB_GNI above 75. & ALB_GNI above 75. \\
& percentile) & percentile) \\
\hline
\end{tabular}

outreach (low outreach, medium outreach and high outreach):

Results in Figure 2 show average values of the different dependent variables of interest for the three levels of outreach defined above. YIELD and
OPEX increase with the level of outreach. The increase of the revenue measure (YIELD) is slightly stronger than the growth of operating expenses (OPEX), resulting in a slightly increasing average difference between the two measures with higher levels of outreach. This indicates that operating expenses are overcompensated by interest rates charged at higher levels of outreach. As a result, the profit margin (MARGIN) increases with outreach. Interestingly, the relation with the two outreach variables is only significant in the HT model, but not using a standard OLS regression or random effects method (see Table 4). The relation with the variable FEMALE is even negative (not at a significant level) in the standard OLS regression. This points to the fact that the relation between outreach and MARGIN seems not to be as strong as the relation with the other dependent variables.

ROA and OSS are on average constant over different levels of outreach, and ROE reaches its peak at medium outreach. These descriptive results thus clearly support the three hypotheses defined above and provide evidence for the expectation that more outreach involves higher yield 
Table 5. Outreach and financial performance: Hausman Taylor regression using data from 2004 to 2013 (453 MFIs).

\begin{tabular}{|c|c|c|c|c|c|c|c|}
\hline VARIABLES & (1) OPEX & (2) YIELD & (3) YIELDR & (4) $\mathrm{ROA}$ & (5) $\mathrm{ROE}$ & (6) OSS & (7) MARGIN \\
\hline FEMALE & $\begin{array}{l}0.054^{* * *} \\
(3.455)\end{array}$ & $\begin{array}{l}0.083^{* * *} \\
(3.611)\end{array}$ & $\begin{array}{c}0.047^{*} \\
(1.786)\end{array}$ & $\begin{array}{l}0.042^{* *} \\
(2.354)\end{array}$ & $\begin{array}{l}-0.038 \\
(-0.131)\end{array}$ & $\begin{array}{c}0.134 \\
(1.193)\end{array}$ & $\begin{array}{c}0.150^{*} \\
(1.788)\end{array}$ \\
\hline ALB_GNI & $\begin{array}{l}-0.010^{* * *} \\
(-2.757)\end{array}$ & $\begin{array}{l}-0.031^{* * *} \\
(-5.490)\end{array}$ & $\begin{array}{l}-0.028^{* * *} \\
(-4.355)\end{array}$ & $\begin{array}{l}-0.006 \\
(-1.327)\end{array}$ & $\begin{array}{c}0.010 \\
(0.140)\end{array}$ & $\begin{array}{c}0.014 \\
(0.521)\end{array}$ & $\begin{array}{l}-0.044^{* *} \\
(-2.134)\end{array}$ \\
\hline SIZE & $\begin{array}{l}-0.045^{* * *} \\
(-17.463)\end{array}$ & $\begin{array}{l}-0.013^{* * *} \\
(-3.537)\end{array}$ & $\begin{array}{l}-0.017^{* * *} \\
(-4.254)\end{array}$ & $\begin{array}{l}0.024^{* * *} \\
(9.465)\end{array}$ & $\begin{array}{l}0.085^{* * *} \\
(3.467)\end{array}$ & $\begin{array}{l}0.051^{* * *} \\
(4.247)\end{array}$ & $\begin{array}{l}0.155^{* * *} \\
(12.692)\end{array}$ \\
\hline PAR30 & $\begin{array}{l}-0.002 \\
(-0.095)\end{array}$ & $\begin{array}{l}-0.024 \\
(-0.665)\end{array}$ & $\begin{array}{c}0.008 \\
(0.202)\end{array}$ & $\begin{array}{l}-0.185^{* * *} \\
(-6.750)\end{array}$ & $\begin{array}{l}-0.137 \\
(-0.371)\end{array}$ & $\begin{array}{l}-0.763^{* * *} \\
(-4.860)\end{array}$ & $\begin{array}{l}-0.630^{* * *} \\
(-4.860)\end{array}$ \\
\hline LEVERAGE & $\begin{array}{l}0.026^{* *} \\
(2.317)\end{array}$ & $\begin{array}{l}-0.011 \\
(-0.666)\end{array}$ & $\begin{array}{c}0.007 \\
(0.394)\end{array}$ & $\begin{array}{l}-0.067^{* * *} \\
(-5.333)\end{array}$ & $\begin{array}{c}0.289 \\
(1.617)\end{array}$ & $\begin{array}{l}-0.165^{* *} \\
(-2.218)\end{array}$ & $\begin{array}{l}-0.249^{* * *} \\
(-4.206)\end{array}$ \\
\hline BANK & $\begin{array}{l}-0.030 \\
(-1.383)\end{array}$ & $\begin{array}{l}-0.050^{*} \\
(-1.771)\end{array}$ & $\begin{array}{l}-0.042 \\
(-1.437)\end{array}$ & $\begin{array}{l}-0.031^{*} \\
(-1.744)\end{array}$ & $\begin{array}{c}0.018 \\
(0.128)\end{array}$ & $\begin{array}{l}-0.087 \\
(-1.195)\end{array}$ & $\begin{array}{l}-0.166^{*} \\
(-1.908)\end{array}$ \\
\hline COOP & $\begin{array}{l}-0.064^{* * *} \\
(-2.830)\end{array}$ & $\begin{array}{l}-0.118^{* * *} \\
(-3.980)\end{array}$ & $\begin{array}{l}-0.107^{* * *} \\
(-3.604)\end{array}$ & $\begin{array}{c}-0.002 \\
(-0.128)\end{array}$ & $\begin{array}{c}0.051 \\
(0.381)\end{array}$ & $\begin{array}{c}-0.004 \\
(-0.064)\end{array}$ & $\begin{array}{c}0.020 \\
(0.229)\end{array}$ \\
\hline NGO & $\begin{array}{l}-0.017 \\
(-1.089)\end{array}$ & $\begin{array}{l}-0.010 \\
(-0.472)\end{array}$ & $\begin{array}{l}-0.018 \\
(-0.848)\end{array}$ & $\begin{array}{c}0.022^{*} \\
(1.797)\end{array}$ & $\begin{array}{l}0.161^{*} \\
(1.787)\end{array}$ & $\begin{array}{c}0.075 \\
(1.572)\end{array}$ & $\begin{array}{c}0.106^{*} \\
(1.725)\end{array}$ \\
\hline OTHER & $\begin{array}{c}0.034 \\
(0.222)\end{array}$ & $\begin{array}{c}0.019 \\
(0.101)\end{array}$ & $\begin{array}{c}0.005 \\
(0.029)\end{array}$ & $\begin{array}{c}0.030 \\
(0.273)\end{array}$ & $\begin{array}{l}-0.007 \\
(-0.009)\end{array}$ & $\begin{array}{c}0.152 \\
(0.386)\end{array}$ & $\begin{array}{c}0.107 \\
(0.198)\end{array}$ \\
\hline RURBANK & $\begin{array}{l}-0.177^{* * *} \\
(-2.980)\end{array}$ & $\begin{array}{l}-0.105 \\
(-1.387)\end{array}$ & $\begin{array}{c}-0.119 \\
(-1.586)\end{array}$ & $\begin{array}{c}0.061 \\
(1.378)\end{array}$ & $\begin{array}{c}0.326 \\
(0.910)\end{array}$ & $\begin{array}{c}0.136 \\
(0.780)\end{array}$ & $\begin{array}{c}0.348 \\
(1.596)\end{array}$ \\
\hline AFRICA & $\begin{array}{c}0.065^{* *} \\
(2.272)\end{array}$ & $\begin{array}{c}0.021 \\
(0.587)\end{array}$ & $\begin{array}{l}-0.006 \\
(-0.166)\end{array}$ & $\begin{array}{c}-0.021 \\
(-0.989)\end{array}$ & $\begin{array}{c}-0.079 \\
(-0.527)\end{array}$ & $\begin{array}{l}-0.143^{*} \\
(-1.827)\end{array}$ & $\begin{array}{c}-0.122 \\
(-1.183)\end{array}$ \\
\hline ECA & $\begin{array}{l}-0.003 \\
(-0.134)\end{array}$ & $\begin{array}{l}-0.026 \\
(-0.811)\end{array}$ & $\begin{array}{l}-0.053^{*} \\
(-1.660)\end{array}$ & $\begin{array}{c}0.019 \\
(1.017)\end{array}$ & $\begin{array}{c}0.010 \\
(0.067)\end{array}$ & $\begin{array}{c}0.030 \\
(0.409)\end{array}$ & $\begin{array}{c}0.026 \\
(0.282)\end{array}$ \\
\hline LAC & $\begin{array}{l}0.049^{* *} \\
(2.042)\end{array}$ & $\begin{array}{c}0.002 \\
(0.077)\end{array}$ & $\begin{array}{c}0.025 \\
(0.815)\end{array}$ & $\begin{array}{c}-0.008 \\
(-0.471)\end{array}$ & $\begin{array}{l}-0.026 \\
(-0.198)\end{array}$ & $\begin{array}{c}-0.094 \\
(-1.372)\end{array}$ & $\begin{array}{c}-0.122 \\
(-1.372)\end{array}$ \\
\hline MENA & $\begin{array}{c}0.011 \\
(0.267)\end{array}$ & $\begin{array}{l}-0.058 \\
(-1.149)\end{array}$ & $\begin{array}{l}-0.027 \\
(-0.541)\end{array}$ & $\begin{array}{l}-0.020 \\
(-0.690)\end{array}$ & $\begin{array}{c}-0.129 \\
(-0.659)\end{array}$ & $\begin{array}{c}-0.062 \\
(-0.585)\end{array}$ & $\begin{array}{c}-0.224 \\
(-1.563)\end{array}$ \\
\hline SA & $\begin{array}{l}-0.073^{* * *} \\
(-2.637)\end{array}$ & $\begin{array}{l}-0.144^{* * *} \\
(-4.055)\end{array}$ & $\begin{array}{l}-0.150^{* * *} \\
(-4.266)\end{array}$ & $\begin{array}{l}-0.031 \\
(-1.469)\end{array}$ & $\begin{array}{c}0.116 \\
(0.680)\end{array}$ & $\begin{array}{l}-0.148^{*} \\
(-1.776)\end{array}$ & $\begin{array}{l}-0.175^{*} \\
(-1.707)\end{array}$ \\
\hline Time FE & Included & Included & Included & Included & Included & Included & Included \\
\hline Constant & $\begin{array}{c}0.846^{* * *} \\
(19.853)\end{array}$ & $\begin{array}{l}0.572^{* * *} \\
(9.575)\end{array}$ & $\begin{array}{l}0.582^{* * *} \\
(9.035)\end{array}$ & $\begin{array}{l}-0.345^{* * *} \\
(-8.302)\end{array}$ & $\begin{array}{l}-0.981^{* *} \\
(-2.107)\end{array}$ & $\begin{array}{c}0.447^{* *} \\
(2.151)\end{array}$ & $\begin{array}{l}-2.212^{* * *} \\
(-11.103)\end{array}$ \\
\hline Observations & 1,805 & 1,805 & 1,805 & 1,805 & 1,805 & 1,805 & 1,805 \\
\hline
\end{tabular}

Robust t-statistics in parentheses

*** $p<0.01,{ }^{* *} p<0.05,{ }^{*} p<0.1$

The dependent variables in this table are the following: OPEX is operating expenses in relation to total assets; yield on portfolio nominal/real (YIELD/R) is the interest and fee income divided by the average loan portfolio; ROA and ROE are returns in relation to total assets and equity, respectively; OSS (operational self-sufficiency) is the degree to which operational income covers expenses, and MARGIN is the profit margin (net operating income divided by operating revenue). The two most important explanatory variables with respect to the Hypotheses are the percentage of female borrowers (FEMALE) and the average loan balance in relation to the GNI per capita (ALB_GNI). All explanatory variables are used as defined above. The following independent exogenous variables are time-invariant: OTHER, RURBANK, AFRICA, ECA, LAC, MENA, SA. The following independent exogenous variables are time-variant: SIZE, PAR30, LEVERAGE, BANK, COOP, NGO.

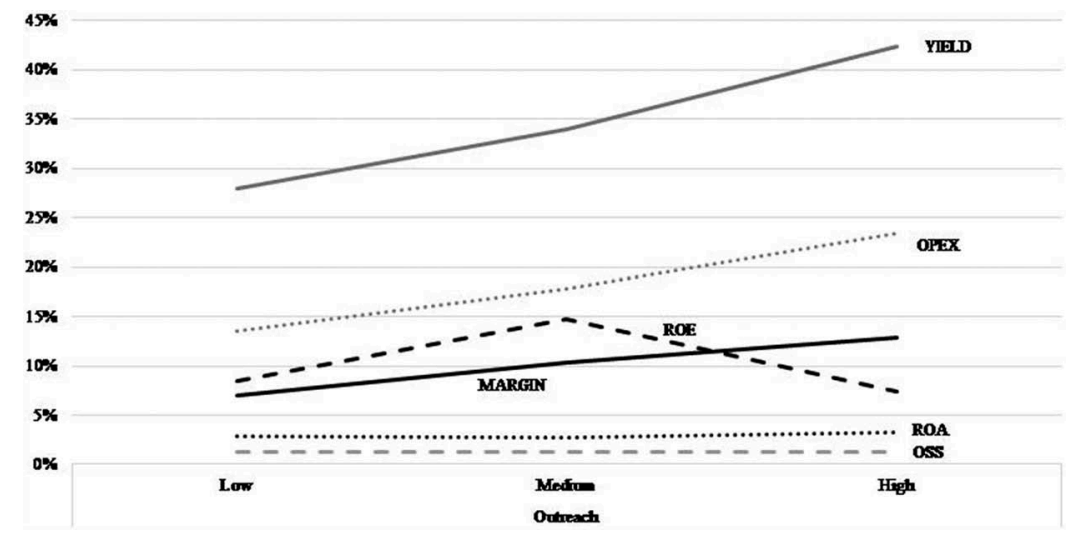

Figure 2. Comparison of variables in relation to levels of outreach.

and higher costs at the same time at a marginal resulting effect on return measures.

With regards to the control variables, we find that the size of the institution (measured using the natural logarithm of total assets), is negatively related to both YIELD and OPEX, but at the same time positively linked to all return measures and the profit margin. This means that larger institutions can 
benefit from economies of scale by reducing operating expenses (and potentially other types of expenses), and therefore achieving better overall financial performance. The portfolio quality measured with the portfolio at risk (30 days) is significantly negatively related to the return measures and the profit margin. For the different types of legal status and regional allocation, we do not find substantial differences in the dependent variables, except that cooperatives seem to incur lower expenses (OPEX) and charge lower interest rates (YIELD/R).

Overall, results for this data set provide support for two hypotheses for both outreach measures, and partial acceptance of the third hypothesis, even when controlling for a large set of variables. ${ }^{15}$

\section{Robustness checks ${ }^{16}$}

Although we include several control variables in the model, it is possible that some correlated variables are omitted. This omission would lead to biased test results. One example is that MFIs located in rural areas serve poorer clients while charging higher interest rates. This situation means that both variables are influenced by the regional allocation of the institution. Other than that, the mission of a particular MFI or the obligations imposed by donors or investors could lead to serving poorer clients at higher prices. Also, the management quality or the quality of human resources might influence both the dependent and the independent variables at the same time. To test for possibly omitted variables, we use a form of a fixed effects model and include 452 dummy variables in the regression, accounting for all MFIs and using one as the reference group. The inclusion of a dummy variable per MFI allows different intercepts for each institution (Wooldridge 2003). By monitoring the unobserved heterogeneity among MFIs, the dummy variables control for all the time-constant, unobservable characteristics of the MFIs that could affect the dependent variable (Wooldridge 2003). This is a very strong test, which controls for all the characteristics of the single MFIs that could influence the relationship between the independent and the dependent variables.

Regarding OPEX, the effect of social return remains statistically significant for both outreach variables. Both coefficients increase for OPEX, with FEMALE slightly increasing from 0.054 to 0.059 and ALB_GNI from -0.010 to -0.011 , indicating that no institution-specific variable influences both the explanatory factors and the dependent variable OPEX at the same time.

With regard to hypothesis 2 (with YIELD as a dependent variable), the value of both coefficients is constant when institutional fixed effects are included (see Table 6). The positive relationship between social performance and nominal yield persists with strong statistical significance at the $1 \%$ level, even after the inclusion of fixed effects.

The effect for the real yield is only weakly significant at the $10 \%$ level in the fixed effects model for the variable FEMALE, while the coefficient for ALB_GNI remains strongly significant. However, the coefficients were already smaller for real than for nominal yield in the random effects HT regression. This could indicate that if MFIs adjust interest rates according to the characteristics of the client or the loan size, they do it on a nominal level, not by considering the national price level.

The coefficients of ROE and OSS remain statistically insignificant as in the original model, meaning that hypothesis 3 is again confirmed, even when taking unobservable effects into account. The coefficient of FEMALE in the model with ROA as dependent variable slightly decreases after the inclusion of fixed effects and remains only weakly significant. This indicates that part of the relationship between ROA and FEMALE is erased through other factors influencing both variables.

The level of significance of the effects for the dependent variable MARGIN decrease when controlling for institutional fixed effects (for ALB_GNI) or completely disappear (for FEMALE). This result confirms our expectation that the relationship between

\footnotetext{
${ }^{15}$ When including all MFIs in the analysis, without controlling for the number of diamonds, the results for hypotheses 1 and 2 remain significant. The regression estimation contains 6,116 observations and leads to similar coefficients, significant at the $1 \%$ level. Regarding ROE and OSS, small differences result when all diamonds are included. ROE is positively influenced by FEMALE, significant at the 5\% level, and OSS is positively connected to ALB_GNI (significant at the $5 \%$ level), indicating that lower outreach involves higher values of OSS. However, as stated above, some MFIs with low diamond scores report implausible results, and these scarcely significant results are therefore probably not valid.

${ }^{16}$ In addition to the regression diagnostic tests presented here, more tests have been conducted (multicollinearity (variance inflation factors), control for outliers, inclusion of all MFIs regardless of their number of diamonds, and so forth) and are available upon request.
} 
Table 6. Outreach and financial performance: institutional (MFI) fixed effects included.

\begin{tabular}{|c|c|c|c|c|c|c|c|}
\hline & (1) & (2) & (3) & (4) & (5) & (6) & (7) \\
\hline VARIABLES & OPEX & YIELD & YIELDR & ROA & ROE & OSS & MARGIN \\
\hline $\begin{array}{l}\text { Institution Fixed } \\
\text { Effects }\end{array}$ & Included & Included & Included & Included & Included & Included & Included \\
\hline FEMALE & $\begin{array}{c}0.059^{* * *} \\
(3.639)\end{array}$ & $\begin{array}{c}0.084^{* * *} \\
(3.547)\end{array}$ & $\begin{array}{l}0.050^{*} \\
(1.833)\end{array}$ & $\begin{array}{l}0.036^{*} \\
(1.914)\end{array}$ & $\begin{array}{c}0.091 \\
(0.297)\end{array}$ & $\begin{array}{c}0.108 \\
(0.907)\end{array}$ & $\begin{array}{c}0.112 \\
(1.233)\end{array}$ \\
\hline ALB_GNI & $\begin{array}{c}-0.011^{* * *} \\
(-2.880)\end{array}$ & $\begin{array}{c}-0.031^{* * *} \\
(-5.339)\end{array}$ & $\begin{array}{c}-0.028^{* * *} \\
(-4.247)\end{array}$ & $\begin{array}{l}-0.005 \\
(-1.051)\end{array}$ & $\begin{array}{l}-0.007 \\
(-0.100)\end{array}$ & $\begin{array}{c}0.025 \\
(0.853)\end{array}$ & $\begin{array}{l}-0.038^{*} \\
(-1.693)\end{array}$ \\
\hline Controls & Included & Included & Included & Included & Included & Included & Included \\
\hline Time FE & Included & Included & Included & Included & Included & Included & Included \\
\hline Constant & $\begin{array}{l}0.892^{* * *} \\
(13.369)\end{array}$ & $\begin{array}{c}0.867^{* * *} \\
(8.850)\end{array}$ & $\begin{array}{c}0.754^{* * *} \\
(6.731)\end{array}$ & $\begin{array}{l}-0.163^{* *} \\
(-2.086)\end{array}$ & $\begin{array}{l}-1.270 \\
(-1.004)\end{array}$ & $\begin{array}{c}1.501^{* * *} \\
(3.058)\end{array}$ & $\begin{array}{c}-2.113^{* * *} \\
(-5.610)\end{array}$ \\
\hline Observations & 1,805 & 1,805 & 1,805 & 1,805 & 1,805 & 1,805 & 1,805 \\
\hline R-squared & 0.900 & 0.895 & 0.863 & 0.709 & 0.358 & 0.542 & 0.639 \\
\hline
\end{tabular}

t-statistics in parentheses

*** $\mathrm{p}<0.01,{ }^{* *} \mathrm{p}<0.05, * \mathrm{p}<0.1$

The dependent variables in this table are the following: OPEX is operating expenses in relation to total assets; Yield on portfolio nominal/real (YIELD/R) is the interest and fee income divided by the average loan portfolio; ROA and ROE are returns in relation to total assets and equity, respectively, OSS (operational self-sufficiency) is the degree to which operational income covers expenses, and MARGIN is the profit margin (net operating income divided by operating revenue). The two most important explanatory variables with respect to the Hypotheses are the percentage of female borrowers (FEMALE) and the average loan balance in relation to the GNI per capita (ALB_GNI). All explanatory variables are used as defined above.

outreach and profit margin is not substantial and probably driven by other unobservable factors.

Not surprisingly, the R-squared increased strongly to between $36 \%$ and $90 \%$ in all models. By including dummies for each MFI we are able to capture much of the variation in the dependent variable.
To conclude, all the hypotheses are confirmed with strong significance, even when controlling for all institution-specific fixed factors.

Another issue that requires attention is the significant negative correlation between the two explanatory variables of interest: FEMALE and ALB_GNI. Therefore, we run the HT model with

Table 7. Outreach and financial performance: Hausman Taylor regression for FEMALE and ALB_GNI separately using data from 2004 to 2013 (453 MFIs).

\begin{tabular}{|c|c|c|c|c|c|c|}
\hline & (1) & (2) & (3) & (4) & (5) & (6) \\
\hline VARIABLES & OPEX & OPEX & YIELD & YIELD & ROA & ROA \\
\hline FEMALE & $\begin{array}{l}0.058^{* * *} \\
(3.770)\end{array}$ & & $\begin{array}{l}0.097^{* * * *} \\
(4.218)\end{array}$ & & $\begin{array}{l}0.045^{* *} \\
(2.526)\end{array}$ & \\
\hline \multicolumn{2}{|l|}{ ALB_GNI } & $\begin{array}{l}-0.012^{* * *} \\
(-3.142)\end{array}$ & & $\begin{array}{l}-0.033^{* * *} \\
(-5.913)\end{array}$ & & $\begin{array}{c}-0.007 \\
(-1.611)\end{array}$ \\
\hline Controls & Included & Included & Included & Included & Included & Included \\
\hline Time FE & Included & Included & Included & Included & Included & Included \\
\hline \multirow[t]{2}{*}{ Constant } & $0.839 * * *$ & $0.889 * * *$ & $0.555^{* * *}$ & $0.642^{* * *}$ & $-0.31^{* * *}$ & $-0.310^{* * *}$ \\
\hline & (19.679) & $(21.827)$ & $(9.200)$ & $(11.272)$ & $(-8.021)$ & $(-8.021)$ \\
\hline \multirow{3}{*}{$\begin{array}{l}\text { Observations } \\
\text { z-statistics in p } \\
*^{* *} p<0.01,\end{array}$} & 1,805 & 1,805 & 1,805 & 1,805 & 1,805 & 1,805 \\
\hline & ${ }^{*} p<0.1$ & & & & & \\
\hline & (7) & (8) & (9) & (10) & (11) & $(12)$ \\
\hline VARIABLES & ROE & ROE & OSS & OSS & MARGIN & MARGIN \\
\hline FEMALE & $\begin{array}{c}-0.043 \\
(-0.153)\end{array}$ & & $\begin{array}{c}0.127 \\
(1.135)\end{array}$ & & $\begin{array}{l}0.171^{* *} \\
(2.047)\end{array}$ & \\
\hline ALB_GNI & & $\begin{array}{c}0.011 \\
(0.159)\end{array}$ & & $\begin{array}{c}0.010 \\
(0.371)\end{array}$ & & $\begin{array}{l}-0.048^{* *} \\
(-2.356)\end{array}$ \\
\hline Controls & Included & Included & Included & Included & Included & Included \\
\hline Time FE & Included & Included & Included & Included & Included & Included \\
\hline \multirow[t]{2}{*}{ Constant } & $-0.979^{* *}$ & $-0.624^{* *}$ & $-0.979^{* *}$ & $0.57^{* * *}$ & $-2.236^{* * *}$ & $-1.02^{* * *}$ \\
\hline & $(-2.103)$ & $(-2.418)$ & $(-2.103)$ & $(3.180)$ & $(-11.217)$ & $(-2.723)$ \\
\hline Observations & 1,805 & 1,805 & 1,805 & 1,805 & 1,805 & 1,805 \\
\hline
\end{tabular}

z-statistics in parentheses

*** $\mathrm{p}<0.01,{ }^{* *} \mathrm{p}<0.05,{ }^{*} \mathrm{p}<0.1$

The dependent variables in this table are the following: OPEX is operating expenses in relation to total assets; yield on portfolio nominal/real (YIELD/R) is the interest and fee income divided by the average loan portfolio; ROA and ROE are returns in relation to total assets and equity, respectively, OSS (operational self-sufficiency) is the degree to which operational income covers expenses, and MARGIN is the profit margin (net operating income divided by operating revenue). The two most important explanatory variables with respect to the Hypotheses are the percentage of female borrowers (FEMALE) and the average loan balance in relation to the GNI per capita (ALB_GNI). All explanatory variables are used as defined above. 
the two variables separately (see Table 7), controlling for the same factors as in the model defined above. We find the same results for the two separate models, with an almost identical size of coefficients and equal level of significance, and can, therefore, accept all the hypotheses based on the individual regression results.

\section{Different types of MFIs}

As the database by MIX used in this paper includes a large set of heterogeneous MFIs, we differentiate our general conclusions for specific categories of MFIs - namely, for institutional types and geographies. Cull, Demirgüç-Kunt, and Morduch (2007) argue that institutional design has an influence on trade-offs between return measures in microfinance. To track conditions under which our results hold, we differentiate our findings based on approaches of institutional classification (Table 8). According to Ledgerwood (1999), financial service providers can be classified into three types: informal, semi-formal and formal institutions. This approach of differentiation is important in our context as we focus on financial return measures that are influenced by the type of formalization (Meyer 2013). Based on the available data and the fact that the MIX database does not capture information on informal institutions, the status of formalization of MFIs can be best proxied through the differentiation into for-profit and not-for-profit institutions and according to the legal status. The results found for the whole sample all hold if running the analysis separately for the set of for-profit institutions (banks, nonbank financial institutions and rural banks) and for the not-for-profits (which include NGOs, cooperative societies and credit unions), respectively. Most results found for all MFIs also prevail if differentiating the sample according to their regulatory status (Table 8), confirming previous research that found no effect of regulation on financial results and outreach (Hartarska and Nadolnyak 2007). Overall results, therefore, indicate that the type of formal status of the institution seems not to be a decisive driver of the interaction between social outreach and financial performance. This finding is particularly interesting because not-for-profit institutions are found to serve poorer households than for-profits do (Cull, Demirgüç-Kunt, and Morduch 2009).

In addition to the institutional setup, idiosyncratic characteristics of the market and competition both have important implications for an MFI's operations. On the one hand, microfinance industries historically developed differently in the broad geographical regions, with for instance group-based and women-focused poverty lending approaches originating from South Asia, cooperative-type institutions long dominating in countries of the West African Economic and Monetary Union and the first transformation of a microenterprise lending for-profits into a bank happening in Bolivia. On the other hand, the option to compensate for higher expenses by augmenting prices is driven by the intensity of

Table 8. Results according to the classification of MFIs.

\begin{tabular}{|c|c|c|c|c|c|c|c|}
\hline Classification & $\mathrm{n}$ & YIELD & YIELDR & OPEX & ROA & ROE & OSS \\
\hline For-profit & 996 & $\mathrm{X}$ & X & $\mathrm{X}$ & $\mathrm{x}$ & $\mathrm{x}$ & $\mathrm{x}$ \\
\hline Not-for-profit & 902 & $\mathrm{x}$ & $X$ (FEM) & $\mathrm{x}$ & $x$ & $x$ & $\mathrm{x}$ \\
\hline Regulated & 1,053 & $\mathrm{x}$ & X & $\mathrm{X}$ & $\mathrm{X}$ & $x$ & $\mathrm{X}$ \\
\hline Not regulated & 747 & $\mathrm{X}$ & $X(F E M)$ & $X(A L B)$ & $X(F E M)$ & $\mathrm{X}$ & $\mathrm{X}$ \\
\hline LAC & 738 & $\mathrm{X}$ & $x$ & $x$ & $x$ & $\mathrm{x}$ & $\mathrm{x}$ \\
\hline ECA & 385 & $\mathrm{x}$ & $X(F E M)$ & X & $\mathrm{x}$ & X & $\mathrm{x}$ \\
\hline MENA & 128 & $x$ & $X(A L B)$ & $X(A L B)$ & $x$ & $X(A L B)$ & $\mathrm{x}$ \\
\hline SA & 196 & $X($ FEM) & & & $\mathrm{X}$ & X & $X$ (FEM) \\
\hline EAP & 53 & $X(F E M)$ & $X(A L B)$ & & $x$ & $\mathrm{x}$ & $x$ \\
\hline Africa & 230 & $X(A L B)$ & & & $\mathrm{x}$ & $x$ & $\mathrm{x}$ \\
\hline Small & 533 & $x$ & $X$ (FEM) & $\mathrm{x}$ & $x$ & $x$ & $\mathrm{x}$ \\
\hline Middle & 845 & $x$ & $x$ & $x$ & $X(A L B)$ & X & $\mathrm{x}$ \\
\hline Large & 427 & $X(A L B)$ & $X(A L B)$ & $X(A L B)$ & $X(A L B)$ & $X(A L B)$ & $\mathrm{x}$ \\
\hline
\end{tabular}

This table depicts the results of the random effects regression using data from 2004 to 2013 according to different types of classification. Fields marked with ' $X$ ' indicate that the results of this specific class are in line with the results for the whole sample found above, meaning that the findings are also significantly different from zero at the $5 \%$ or $1 \%$ level. Empty cells indicate that the results diverge from those found in the full sample. Cells with 'ALB' indicate that the results are at a significant level, in line with those found in the full sample, for the independent variable 'ALB_GNI' only. Cells with 'FEM' indicate that the results are at a significant level, in line with those found in the full sample, for the independent variable 'FEMALE' only. 
competition. Stronger competition should, according to the structure-conduct-performance theory (e.g. Weiss 1974), bring interest rates down in the respective markets. In microfinance, the relation between competition and pricing is not necessarily in favour of the borrowers because with increasing competition, MFIs might start to distribute multiple loans to impatient borrowers (McIntosh and Wydick 2005). This behaviour results in diminishing repayment rates if borrowers apply for multiple loans across different institutions and MFIs fail to share information on their borrowers. De Quidt, Fether, and Ghatak (2016) also show that in competitive markets, borrowers' incentives to repay are negatively affected, as they have access to multiple providers. The result of increasing competition could, therefore, involve less-favourable credit conditions for all clients. Nevertheless, this condition only holds as long as MFIs do not share information and have no access to the credit history of clients, which changes as soon as official credit bureaus emerge. In another approach to classification, we, therefore, consider the regional location of the institution, following the standard regional classification of the World Bank group.

The largest number of MFIs in the sample operate in Latin America and the Caribbean (LAC), followed by Europe and Central Asia (ECA). The results for all hypotheses hold if we look only at MFIs operating in these two regions separately. For MFIs active in the Middle East and Northern Africa (MENA), most of the results hold (though not at a significant level for the variable FEMALE). Also, confirming the results found above, data for MFIs active in Africa, South Asia and East Asia and the Pacific (EAP) indicate no significant relation between the measures of outreach and return (ROA, ROE and OSS). Nevertheless, in those three regions, the relation among measures of depth of outreach, costs, and yield is not in line with the results discussed above. Operating expenses in all three regions are not significantly related to either measure of outreach.
Furthermore, in two regions (Africa and South Asia), the analysis of the variable 'FEMALE' particularly leads to different results. Both yield measures are negatively related to female clients, which means that female clients pay less for their loans in those regions. Furthermore, in South Asia, operating expenses are negatively associated with female clients (not at a significant level). Nevertheless, the results are probably driven by the fact that the majority of clients are female in South Asia (93\%), compared to an average across all data of $63 \%$ female clients.

Because the size of the institution (i.e. total assets) seems to be an important driver of all dependent variables (see Table 5), we also check for differences in results according to total assets. We differentiate three groups (largest: more than USD 50 Million, middle: between USD 5 and 50 Million, smallest: below USD 5 Million total assets). ${ }^{17}$ Whereas the results remain stable for the two groups of smaller MFIs, the results diverge for the largest group for the variable FEMALE. In large institutions, female clients show significantly larger levels of ROA and ROE. At the same time, those larger institutions serve fewer female clients than average (with 53\%, compared to the mean 63\%).

Data limitations prevent us from assessing other important approaches to differentiation. Cull, Demirgüç-Kunt, and Morduch (2007), for example, argue that the type of lending methodology used is important for return and outreach considerations; nevertheless, this variable is not available in our database.

To conclude, the results seem to be robust across different degrees of formalization of MFIs. Nevertheless, size and region are important drivers of the relationship. This means that analyses should ideally be done at a country or even market level, taking specific conditions, such as competition, into account. Furthermore, the variable 'FEMALE' is, in certain markets, probably not the best measure of outreach, as some MFIs still concentrate mostly on female clients, and the variation in the variable is therefore not large enough.

\footnotetext{
${ }^{17}$ This approach is in line with the methodology used by Microrate to distinguish three different groups of MFls: Tier 1, Tier 2 and Tier 3 (see http://www. microrate.com/media/downloads/2013/04/MicroRate-White-paper-Microfinance-Institution-Tier-Definitions.pdf).
} 


\section{Conclusion}

This paper contributes to the discussion on the relationship between social outreach and financial return of microfinance institutions by presenting comprehensive empirical analysis using different financial performance measures. The results indicate that institutions charge female clients and smaller loans higher interest rates. Because operational expenses increase at the same time, the total influence on return measures (such as ROA, ROE, OSS and profit margin) is very small, and in most cases not statistically significant.

These findings suggest that some of the existing studies identifying ambiguous results regarding the relation between financial and social return have not focused on the best choice of variables. Return figures are influenced by both costs and yield at the same time, and both increase with greater depth of outreach. Most previous papers have examined ROA, ROE, OSS or FSS in relation to outreach. All four return measures are positively influenced by yield (earnings) and negatively by costs. Supposing that outreach is positively related to yield (as argued by Conning 1999 and reinforced by the present study) and negatively to costs (supported by Hermes, Lensink, and Meesters 2011; Cull, DemirgüçKunt, and Morduch 2007; Conning 1999 as well as by the present study) the combined effect results in zero or a very weak consequence on return measures. This could explain the contradictory results previously found on the relationship between social and financial return in microfinance (see the present study as well as Cull, Demirgüç-Kunt, and Morduch 2007; Quayes 2012).

We find that the effect between outreach and YIELD is slightly stronger than with OPEX, meaning that higher costs are overcompensated at higher levels of outreach. This is the reason why we find a slightly positive interaction of outreach with ROA and the profit margin, however at a small level.

Our results hold if the data sample is differentiated according to the state of formalization of the MFIs. Nevertheless, the region in which the MFI is active seems to be an important consideration, as the results differ mainly for
MFIs in Africa, South Asia and East Asia and the Pacific. Furthermore, results diverge for the set of largest MFIs (above USD 50 Million total assets), as for those 335 MFIs, the results do not hold for the variable female, which is, in turn, positively related to return measures. These differences point to the fact that competition and size of the institution might be an important driver of the relationship between outreach and financial performance, and, thus, future analyses should concentrate on specific markets and differentiate according to the size of the institutions.

Form an investors' perspective, the results indicate that putting a focus on socially responsible elements in their investment decisions, and accordingly favouring MFIs with a focus on outreach, does not affect financial performance. The expected trade-off between social and financial factors does not seem to exist because higher costs are covered through higher interest rates.

At a national level, an augmentation of interest rates could lead to a 'squeezing out of the market' of the poorest unbanked borrowers. Consequently, total demand and the potential of microfinance to contribute to the development of financial markets would decrease. In addition to the fact that the poorest borrowers would no longer be the main target group for the services offered, the total risk could increase. While charging poorer clients higher interest rates seems to be necessary to overcome higher costs and potential default, this practice is not consistent with the social nature of microfinance institutions. The fact that the poorest clients have to pay the most indicates a somewhat 'unsocial' strategy of the MFIs. Additional analyses on their loan policies might help to identify whether they, in fact, adjust interest rates based on clients' profiles and loan sizes.

At the same time, new technological trends and the techniques and criteria used by MFIs to determine interest rates require further research. The link between operating costs and interest rates could shift as digital finance mechanisms become more important in microfinance. The use of technological innovation could enable MFIs to keep transaction costs low, even for small loan sizes. 


\section{Acknowledgments}

I am very thankful for important input to this research project by Urs Birchler, Alexander Wagner, Annette Krauss, Catalina Martinez, Jonathan Fu, and Timo Busch. Furthermore, I thank the audience of the Financial Economics Doctoral Seminar of Professor Hens in 2011; the audience of the University meets Microfinance Workshop in 2012 and the audience of the Third European Research Conference on Microfinance in 2013. I am greatly indebted to a referee of the journal, who made very important comments that I have since addressed.

\section{Disclosure statement}

No potential conflict of interest was reported by the author.

\section{References}

Abdullah, S., and S. Quayes. 2016. "Do Women Borrowers Augment Financial Performance of MFIs?" Applied Economics 48 (57): 5593-5604.

Angelucci, M., D. Karlan, and J. Zinman. 2015. "Microcredit Impacts: Evidence from a Randomized Microcredit Program Placement Experiment by Compartamos Banco." American Economic Journal: Applied Economics 7 (1): 151-182.

Armendáriz, B., and J. Morduch. 2010. The Economics of Microfinance. Cambridge, MA: MIT Press.

Banerjee, A., D. Karlan, and J. Zinman. 2015. "Six Randomized Evaluations of Microcredit: Introduction and Further Steps." American Economic Journal: Applied Economics 7 (1): 1-21.

Barnett, M. L., and R. M. Salomon. 2006. "Beyond Dichotomy: The Curvilinear Relationship between Social Responsibility and Financial Performance." Strategic Management Journal 27 (11): 1101-1122.

Baum, C. 2006. An Introduction to Modern Econometrics Using Stata. College Station, TX: Stata Press.

Burjorjee, D., and B. Scola. 2015. "New Funder Guidelines: Market Systems Approach to Financial Inclusion." In Consensus Guidelines. Washington, DC: CGAP.

CGAP. 2007. Appraisal Guide for Microfinance Institutions: Resource Guide. Washington, DC: CGAP.

CGAP. May 2012. "How Have Market Challenges Affected Microfinance Investment Funds? Highlights from the CGAP Market Scan.” In CGAP Brief.Washington, DC: CGAP.

CGAP/The World Bank Group. 2003. Microfinance Consensus Guidelines, Definitions of Selected Financial Terms, Ratios, and Adjustments for Microfinance. Washington, DC: CGAP.

Conning, J. 1999. "Outreach, Sustainability and Leverage in Monitored and Peer-Monitored Lending." Journal of Development Economics 60 (1): 51-77.
Copestake, J. 2007. "Mainstreaming Microfinance: Social Performance Management or Mission Drift?" World Development 35 (10): 1721-1738.

Cull, R., A. Demirgüç-Kunt, and J. Morduch. 2007. "Financial Performance and Outreach: A Global Analysis of Leading Microbanks." The Economic Journal 117: F107-F33.

Cull, R., A. Demirgüç-Kunt, and J. Morduch. 2009. "Microfinance Meets the Market." Journal of Economic Perspectives 23 (1): 167-192.

Dam, L. 2008. "Corporate Social Responsibility and Financial Markets." Dissertation, PrintPartners Ipskamp B.V., Enschede, The Netherlands.

De Quidt, J., T. Fether, and M. Ghatak. 2016." Market Structure and Borrower Welfare in Microfinance." CAGE online working paper series 123.

Di Bella, Gabriel 2011. "The Impact of the Global Financial Crisis on Microfinance and Policy Implications." IMF working paper, WP/11/175.

Dieckmann, R. 2007. Microfinance: An Emerging Investment Opportunity. Frankfurt am Main: Deutsche Bank Research.

Dominicié, R. 2012. Microfinance Investments. ISBN: 9782-8399-1093-4. Bellinzona: Symbiotics. ISBN: 978-28399-1093-4.

Drake, D., and E. Rhyne. 2002. The Commercialization of Microfinance: Balancing Business and Development. Bloomfield, CT: A Kumarian Press Book.

Duvendack, M., R. Palmer-Jones, J. Copestake, L. Hooper, Y. Loke, and N. Rao. 2011. What is the Evidence of the Impact of Microfinance on the Well-Being of Poor People? London: EPPI-Centre, Social Science Research Unit, Institute of Education, University of London.

Galema, R., R. Lensink, and L. Spierdijk. 2011. "International Diversification and Microfinance." Journal of International Money and Finance 30 (3): 507-515.

González, A. 2011. "Defining Responsible Financial Performance: Understanding Efficiency." In Mix Microbanking Bulletin. Washington, DC: Microfinance Information Exchange, May.

GPFI and IFC. 2011. Strengthening Access to Finance for Women-Owned SMEs in Developing Countries. Washington, DC: IFC, October.

Green, W. 2012. Econometric Analysis. Seventh edition ed. New York: Prentice Hall.

Hartarska, V., and D. Nadolnyak. 2007. "Do Regulated Microfinance Institutions Achieve Better Sustainability and Outreach? Cross-Country Evidence." Applied Economics 39 (10): 1207-1222.

Hausman, J. A., and W. E. Taylor. 1981. "Panel Data and Unobservable Individual Effects." Econometrica 49 (6): 1377-1398.

Hermes, N., R. Lensink, and A. Meesters. 2011. "Outreach and Efficiency of Microfinance Institutions." World Development 39 (6): 938-948.

Islam, N. 2009. "Can Microfinance Reduce Economic Insecurity and Poverty? by How Much and How?” DESA working paper No. 82. 
Khandker, S. R. 2005. "Microfinance and Poverty: Evidence Using Panel Data from Bangladesh." The World Bank Economic Review 19 (2): 263-286.

Krauss, N., and I. Walter. 2008. "Can Microfinance Reduce Portfolio Volatility?” NYU working paper no. FIN-06-034, available at SSRN: http://ssrn.com/abstract=1300771

Kyereboah-Coleman, A. 2007. "The Impact of Capital Structure on the Performance of Microfinance Institutions." The Journal of Risk Finance 8 (1): 56-71.

Ledgerwood, J. 1999. Microfinance Handbook: An Institutional and Financial Perspective. Sustainable Banking with the Poor. Washington, DC: World Bank.

McIntosh, C., and B. Wydick. 2005. "Competition and Microfinance." Journal of Development Economics 78 (2): 271-298.

Meyer, J. 2013. "Investing in Microfinance: An Analysis of Financial and Social Returns." Ph.D. thesis. University of Zurich.

Meyer, J., and A. Krauss. 2015. "Measuring and Aggregating Social Performance of Microfinance Investment Vehicles. CMF working paper series. No.03-2015 March 31st, 2015.

MIX. 2007. MIX MicroBanking Bulletin. Issue No. 15. Microfinance Information Exchange, Autumn.

Morduch, J. 1999. “The Microfinance Promise." Journal of Economic Literature 37 (4): 1569-1614.

Otero, M., and E. Rhyne. 1994. The New World of Microenterprise Finance: Building Healthy Financial Institutions for the Poor. West Hartford, CT: Kumarian Press.

Paxton, J. 2003. “A Poverty Outreach Index and Its Application to Microfinance." Economics Bulletin 9 (2): 1-10.

Petersen, M. A. 2009. "Estimating Standard Errors in Finance Panel Data Sets: Comparing Approaches." The Review of Financial Studies 22 (1): 435-480.

Quayes, S. 2012. "Depth of Outreach and Financial Sustainability of Microfinance Institutions." Applied Economics 44 (26): 3421-3433.
Quayes, S. 2015. "Outreach and Performance of Microfinance Institutions: A Panel Analysis." Applied Economics 47 (18): 1909-1925.

Roodman, D. 2012. Due Diligence: An Impertinent Inquiry into Microfinance. Washington, DC: CGD research trust Books.

Rosenberg, R. 2009. Measuring Results of Microfinance Institutions - Minimum Indicators that Donors and Investors Should Track - A Technical Guide, Consultative Group to Assist the Poor. Washington, DC: World Bank.

Stiglitz, J., and A. Weiss. 1981. "Credit Rationing in Markets with Imperfect Information.” American Economic Review 71 (3): 393-410.

Tchakoute-Tchuigoua, H. 2010. "Is There a Difference in Performance by the Legal Status of Microfinance Institutions?" The Quarterly Review of Economics and Finance 50 (4): 436-442.

Urgeghe, L. 2010. "Les Véhicules d'investissement en microfinance et le défi de la performance sociale." Mondes en Développement 4 (152): 69-82.

Urgeghe, L. 2012. "Microfinance Investments: What are the Impediments to the Integration of Social Performance in Investment Decisions?" Centre de Recherche Warocqué, working paper 2012/1.

Weiss, L. 1974. "The Concentration-Profits Relationship and Antitrust." In Industrial Concentration: The New Learning, edited by $\mathrm{H}$. Goldschmid, H. Mann, and J. Weston, 184-233. Boston: Little, Brown, and Company.

Wooldridge, J. 2003. Introductory Econometrics - A Modern Approach. Mason, $\mathrm{OH}$ : Thomson South Western Cengage Learning.

Zacharias, J. 2008. "An Investigation of Economies of Scale in Microfinance Institutions." Working paper Leonard N. Stern School of Business, Glucksman Institute for Research in Securities Markets. 